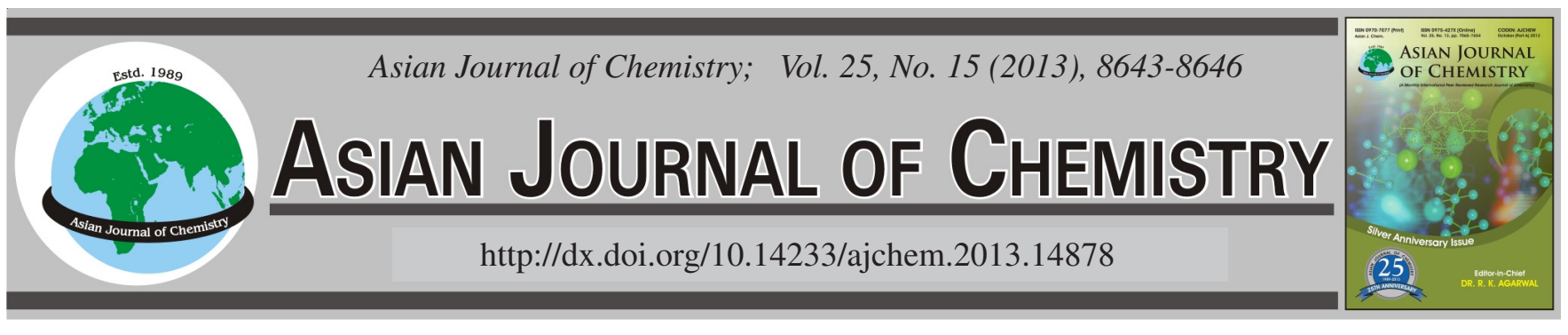

\title{
Synthesis of Novel Schiff Bases by Microwave Irradiation and Their in vitro Antibacterial Activity
}

\author{
Salman A. Khan ${ }^{1, *}$, Abdullah M. Asiri ${ }^{1,2}$, Aftab Aslam Parwaz Khan ${ }^{1,2}$, Khalid Ali Khan ${ }^{1}$ and Mohie A.M. Zayed $^{1}$
}

${ }^{1}$ Department of Chemistry, Faculty of Science, King Abdulaziz University, P.O. Box 80203, Jeddah 21589, Kingdom of Saudi Arabia ${ }^{2}$ Center of Excellence for Advanced Materials Research, King Abdulaziz University, P.O. Box 80203, Jeddah 21589, Kingdom of Saudi Arabia

*Corresponding author: Fax: +966 2 6952292; E-mail: sahmad_phd@yahoo.co.in

(Received: 26 November 2012;

Accepted: 26 August 2013)

AJC-14016

\begin{abstract}
A series of thiophene-3-carbonitrile contaning schiff bases were synthesized, characterized by the reaction of 2-amino-4,5,6,7-tetrahydrobenzo[b]thiophene-3-carbonitrile and corresponding active aldehyde under microwave irradiation and screened for their antibacterial activities. The structure of synthesized compounds were established by spectroscopic (FT-IR, ${ }^{1} \mathrm{H}$ NMR, ${ }^{13} \mathrm{C}$ NMR, Mass) and elemental analyses. The antibacterial activity of these compounds were first tested in vitro by the disk diffusion assay against two Gram-positive and two Gram-negative bacteria and then the minimum inhibitory concentration was determined with the reference of standard drug chloramphenicol. The results showed that compound $\mathbf{6}$ is better at inhibiting the growth as compared to chloramphenicol against both types of the bacteria (gram-positive and gram-negative).
\end{abstract}

Key Words: Schiff bases, Microwave, Chloramphenicol, Antibacterial activity.

\section{INTRODUCTION}

Infectious diseases are the main cause of mortality in the world and the resistance of pathogenic bacteria towards available antibiotics is rapidly becoming a major worldwide problem, hence the design of new compounds to deal with resistant bacteria has become one of the most important areas of antibacterial research today. Food poisoning, rheumatic, salmonellosis and diarrhoea are the second leading cause of death from bacterial disease world-wide ${ }^{1}$. More than 50 million people worldwide are infected and up to 1,50,000 die every year due to these bacterial infections ${ }^{2}$. Moreover drug resistance in food poisoning, rheumatic, salmonellosis and diarrhea can be attributed to the use of drugs (amoxicillin, norfloxacin, ciprofloxacin chloramphenicol) for treatment and to the adaptation of the bacterial parasite by developing alternate pathways for survival ${ }^{3,4}$. Hence, the present work is aimed towards developing novel molecules with improved potential for treating bacterial infections and with decreased probability for developing drug resistance. Schiff bases, named for Hugo Schiff, are formed when any primary amine reacts with an aldehyde or acetone under specific conditions ${ }^{5}$. Structurally, Schiff base (also known as imine or azomethine) is a nitrogen analogue of an aldehyde or ketone in which the carbonyl group $(\mathrm{C}=\mathrm{O})$ has been replaced by an imine or azomethine group ${ }^{6}$. Schiff bases are some of the most widely used organic compounds. They are used as pigments and dyes ${ }^{7}$, catalysts $^{8}$, intermediates inorganic synthesis ${ }^{9}$ and polymer stabilizers $^{10}$. Schiff bases have also been shown to exhibit abroad range of biological activities, including antifungal ${ }^{11}$, antibacterial $^{12}$, antimalarial ${ }^{13}$, antiproliferative ${ }^{14}$, antiinflammatory ${ }^{15}$, antiviral ${ }^{16}$ and antipyretic properties ${ }^{17}$. Its also applicabile in materials fields such as non-linear optical ${ }^{18}$, optical limiting ${ }^{19}$, electrochemical sensing ${ }^{20}$, langmuir film and photoinitiated polymerization ${ }^{21}$. Five member heterocyclic compounds with sulphur and nitrogen containing are abundant in nature and are of great significance to life because their structural subunits exist in many natural products such as vitamins, hormones, antibiotics etc. Compounds with a pyrazoline structure are known to possess tranquilizing muscle relaxing $^{22}$, hypnotic ${ }^{23}$, ulcerogenic ${ }^{24}$, antidepressant ${ }^{25}$, antibacterial $^{26}$, antifungal ${ }^{27}$, analgesic and antiinflammatory properties $^{28}$. Sulphur and nitrogen containing Schiff bases dramatically increase the biological activity such as antifungal, antibacterial, antimalarial, antiproliferative, antiinflammatory, antiviral and antipyreticproperties ${ }^{29,30}$. Lot of research has been carried out on Schiff base derivatives as biological applicable but no work has been done on this type heterocyclic containing Schiff base products screening on bacteria. In this paper we are reporting synthesis and characterizations novel heterocyclic Schiff base under microwave irradiation as antibac terial agent. 


\section{EXPERIMENTAL}

Aldehydes have used from Acros Organic and used without further purification. Other solvents (A.R.) and reagents were obtained commercially and used without further purification except for dimethylformamide (DMF), ethanol and methanol. Melting points were recorded on a Thomas Hoover capillary melting apparatus without correction. IR spectra were taken on $\mathrm{KBr}$ disks on a Nicolet Magna 520 FTIR spectrometer, ${ }^{1} \mathrm{H}$ NMR and ${ }^{13} \mathrm{C}$ NMR were recorded in $\mathrm{CDCl}_{3}$ on a Brucker DPX $600 \mathrm{MHz}$ spectrometer using TMS as internal standard. Microanalyses were carried out using a Perkin Elmer 240B analyzer.

Synthesis of Schiff bases: The Schiff base derivatives were synthesized by using the literature procedure (SchemeI $^{31}$. A mixture of 2-amino-4,5,6,7-tetrahydro-benzo[b] thiophene3 -carbonitrile and $(5.8 \mathrm{mmol})$ and corresponding active aldehyde. $(5.8 \mathrm{mmol})$ in anhydrous methanol $(10 \mathrm{~mL})$, in a beaker $(100 \mathrm{~mL})$, in the presence of few drop of acetic acid and the reaction mixture was heated inside a microwave oven for 2-5 $\min$ (at $210 \mathrm{~W}$, i.e. $30 \%$ microwave power). Progress of reaction was monitored by TLC. After completion of the reaction cooling the reaction mixture, a good yield were obtained and recrystallized from chloroform and ethanol (9:1), giving crystals (1-6).

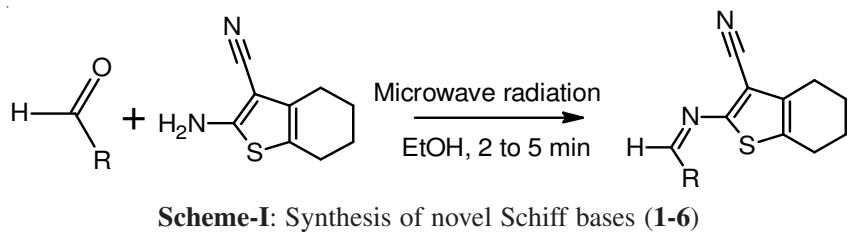

2-\{[(E)-1,3-benzodioxol-5-ylmethylidene $]$ amino $\}$ 4,5,6,7-tetrahydro-1-benzothiophene-3-carbonitrile (1): IR $\left(\mathrm{KBr}, \mathrm{v}_{\max }, \mathrm{cm}^{-1}\right): 2934(\mathrm{C}-\mathrm{H}), 1573(\mathrm{HC}=\mathrm{N}), 1137(\mathrm{C}-\mathrm{N}), 771$ $(\mathrm{C}-\mathrm{S}) ;{ }^{1} \mathrm{H}$ NMR $\left(600 \mathrm{MHz}, \mathrm{CDCl}_{3}\right)(\delta / \mathrm{ppm}): 8.27$ (s, CH olefinic), $7.50(\mathrm{~s}, \mathrm{CH}), 7.29(\mathrm{~d}, \mathrm{CH}, J=8.4 \mathrm{~Hz}), 6.87(\mathrm{~d}, \mathrm{CH}, J=$ $8.4 \mathrm{~Hz}$ ), 6.05 (s, - $\left.\mathrm{CH}_{2}\right), 2,69-1.23\left(\mathrm{~m}, 8 \mathrm{H}, \mathrm{CH}_{2}-\mathrm{cyclic}\right) ;{ }^{13} \mathrm{C}$ NMR $\left(\mathrm{CDCl}_{3}\right) \delta: 160.15,158.10,151.50,148.57,134.92$, $131.78,129.96,127.00,114.68,108.32$, 107.16, 106.18; EIMS m/z (rel. int.\%): 312 (58) [M+1] $]^{+.}$; Anal. calcd. for $\mathrm{C}_{17} \mathrm{H}_{14} \mathrm{~N}_{2} \mathrm{O}_{2} \mathrm{~S}: \mathrm{C}, 65.79, \mathrm{H}, 4.55, \mathrm{~N}, 9.03$, Found: C, 65.75, H, $4.51, \mathrm{~N}, 8.98$.

2-\{[(E)-(4-methoxyphenyl)methylidene $]$ amino $\}$ 4,5,6,7-tetrahydro-1-benzothiophene-3-carbonitrile (2): IR $\left(\mathrm{KBr}, V_{\max } \mathrm{cm}^{-1}\right)$ : 2936(C-H), 1594(C=C), $1558(\mathrm{C}=\mathrm{N})$, 1135(C-N), 771(C-S); ${ }^{1} \mathrm{H}$ NMR $\left(\mathrm{CDCl}_{3}\right) \delta: 8.34(\mathrm{~s}, 1 \mathrm{H}, \mathrm{CH}$ olefinic), 7.89 (d, CH, $J=6.6 \mathrm{~Hz}), 7.88(\mathrm{~d}, \mathrm{CH}, J=6.2 \mathrm{~Hz})$, $6.98(\mathrm{~d}, \mathrm{CH}, J=6.8 \mathrm{~Hz}), 1.899-1.82\left(\mathrm{~m}, 8 \mathrm{H}-\mathrm{CH}_{2}\right.$-cyclic), $2.60\left(\mathrm{~s},-\mathrm{OCH}_{3}\right) ;{ }^{13} \mathrm{C} \mathrm{NMR}\left(\mathrm{CDCl}_{3}\right) \delta: 163.09,160.61,158.39$, 134.84, 131.50, 131.39, 127.97, 114.78, 114.36, 105.88, 58.46, 55.51, 25.16, 24.28, 23.08, 22.01, 18.42; EI-MS m/z (rel. int.\%): 298 (65) $[\mathrm{M}+1]^{+.}$; Anal. calcd. for $\mathrm{C}_{17} \mathrm{H}_{16} \mathrm{~N}_{2} \mathrm{OS}$ : C, 68.89, H, 5.44, N, 9.45, Found: C, 68.84, H, 5.41, N, 9.39.

2-\{[(E)-(2,4,5-trimethoxyphenyl)methylidene $]$ amino $\}$ 4,5,6,7-tetrahydro-1-benzothiophene-3-carbonitrile (3): IR $\left(\mathrm{KBr}, \nu_{\max } \mathrm{cm}^{-1}: 2932(\mathrm{C}-\mathrm{H}), 1586(\mathrm{C}=\mathrm{C}), 1562(\mathrm{C}=\mathrm{N}), 1127(\mathrm{C}-\right.$ $\mathrm{N}), 759(\mathrm{C}-\mathrm{S}) ;{ }^{1} \mathrm{H} \mathrm{NMR}\left(\mathrm{CDCl}_{3}\right) \delta: 8.77$ (s, $\mathrm{CH}$ olefinic), 7.70 (s, CH), 6.47 (s, CH), $3.96\left(\mathrm{~s}, \mathrm{OCH}_{3}\right), 3.94\left(\mathrm{~s}, \mathrm{OCH}_{3}\right), 3.90$ (s, $\left.-\mathrm{OCH}_{3}\right), 2.69-1.83\left(\mathrm{~m}, 8 \mathrm{H},-\mathrm{CH}_{2}\right.$-cyclic); ${ }^{13} \mathrm{C} \mathrm{NMR}\left(\mathrm{CDCl}_{3}\right)$ $\delta: 161.86,156.16,154.45,15.27,143.72,134.68,130.95$, 115.52, 114.97, 108.97, 105.09, 95.83, 58.47, 56.32, 56.26, 56.10, 25.15, 28.47, 56.32, 56.26, 56.10, 25.15, 24.30, 23.12, 22.05, 18.43; EI-MS m/z (rel. int. \%): 358(62) [M+1] ${ }^{+.}$; Anal. calcd. for $\mathrm{C}_{19} \mathrm{H}_{20} \mathrm{~N}_{2} \mathrm{O}_{3} \mathrm{~S}$ : C, 64.02, H, 5.66, N, 7.86, Found: C, 63.98, H, 5.62, N, 7.83.

2-\{[(E)-(3,4-dimethoxyphenyl)methylidene $]$ amino $\}-$ 4,5,6,7-tetrahydro-1-benzothiophene-3-carbonitrile (4): IR $\left(\mathrm{KBr}, \mathrm{v}_{\max }, \mathrm{cm}^{-1}\right)$ : 2925(C-H), $1595(\mathrm{C}=\mathrm{C}), 1566(\mathrm{C}=\mathrm{N}), 1159$ $(\mathrm{C}-\mathrm{N}), 750(\mathrm{C}-\mathrm{S}) ;{ }^{1} \mathrm{H} \mathrm{NMR}\left(\mathrm{CDCl}_{3}\right) \delta: 8.33(\mathrm{~s}, 1 \mathrm{H}$, CHolefinic), 7.62 (s, CH), 7.36 (d, CH, $J=1.8 \mathrm{~Hz}), 6.93$ (d, $\mathrm{CH}, J=3.8 \mathrm{~Hz}), 3.99\left(\mathrm{~s},-\mathrm{OCH}_{3}\right), 3.95\left(\mathrm{~s},-\mathrm{OCH}_{3}\right), 2.70-1.83$ (m, $-\mathrm{CH}_{2}$-cyclic) ${ }^{13} \mathrm{C} \mathrm{NMR}\left(\mathrm{CDCl}_{3}\right) \delta: 160.48,158.66,152.95$, $149.50,134.97,131.17,128.30,125.51,114.74,110.48$, 109.23, 105.78, 58.48, 56.08, 56.03, 25.17, 24.31, 23.08, 22.01, 18.43; EI-MS m/z (rel. int. \%): 328 (72) [M+1] $]^{+.}$; Anal. calcd. for $\mathrm{C}_{18} \mathrm{H}_{18} \mathrm{~N}_{2} \mathrm{O}_{2} \mathrm{~S}$ : C, 66.23, H, 5.56, N, 8.58, Found: C, 66.19, H, 5.52, N, 8.51.

2-\{[(E)-(9-ethyl-9H-carbazol-3-yl)methylidene $]-$ a mino - 4,5,6,7 - tetrahyd ro- 1 - benzothiophene-3carbonitrile (5): $\mathrm{IR}\left(\mathrm{KBr}, \mathrm{v}_{\max } \mathrm{cm}^{-1}\right): 2935(\mathrm{C}-\mathrm{H}), 1586(\mathrm{C}=\mathrm{C})$, $1558(\mathrm{HC}=\mathrm{N}), 1123(\mathrm{C}-\mathrm{N}), 746(\mathrm{C}-\mathrm{S}) ;{ }^{1} \mathrm{H}$ NMR $(600 \mathrm{MHz}$, $\left.\mathrm{CDCl}_{3}\right) \delta: 8.55$ (s, $1 \mathrm{H}, \mathrm{CH}$ olefinic), $8.15(\mathrm{~d}, \mathrm{CH}, J=7.8 \mathrm{~Hz})$, 8.11 (d, CH, $J=8.4 \mathrm{~Hz}$ ), 7.51 (dd, CH, $J=1.2 \mathrm{~Hz}$ ), 7.42 (dd, $\mathrm{CH}, J=2.4 \mathrm{~Hz}), 7.30$ (s, CH), 4.38 (q, $\mathrm{N}-\mathrm{CH}_{2}-\mathrm{CH}_{3}, \mathrm{~Hz}, J=$ $6.6 \mathrm{~Hz}), 1.25$ (t, N-CH$\left.-\mathrm{CH}_{3}, J=7.2\right), 2.69-1.46(\mathrm{~m}, 8 \mathrm{H}$, $-\mathrm{CH}_{2^{-}}$,cyclic); ${ }^{13} \mathrm{C} \mathrm{NMR}\left(\mathrm{CDCl}_{3}\right) \delta: 161.27,159.93,142.51$, $140.44,134.70,130.94,128.32,127.12,126.27,123.21$, 122.90, 120.81, 119.97, 115.06, 108.89, 105.89, 58.46, 37.81, 25.16, 24.30, 23.12, 22.04, 18.42, 13.87; EI-MS m/z (rel. int. \%): 385 (64) $[\mathrm{M}+1]^{+}$; Anal. calcd. for $\mathrm{C}_{24} \mathrm{H}_{21} \mathrm{~N}_{3} \mathrm{~S}$ : C, 75.16, H, 5.09, N, 10.92, Found: C, 75.12, H, 5.01, N,8.88.

2-\{[(E)-(4-chlorophenyl)methylidene $]$ amino $\}-4,5,6,7-$ tetrahydro-1-benzothiophene-3-carbonitrile (6): IR ( $\mathrm{KBr}$, $\left.v_{\max }, \mathrm{cm}^{-1}\right): 2942(\mathrm{C}-\mathrm{H}), 1592(\mathrm{C}=\mathrm{C}), 1558(\mathrm{C}=\mathrm{N}), 1133(\mathrm{C}-\mathrm{N})$, $756(\mathrm{C}-\mathrm{S}) ;{ }^{1} \mathrm{H}$ NMR $\left(\mathrm{CDCl}_{3}\right) \delta: 8.36((\mathrm{~s}, 1 \mathrm{H}, \mathrm{CH}$ olefinic $)$, 7.86 (d, CHaromatic, $J=1.2 \mathrm{~Hz}), 7.86(\mathrm{~d}, \mathrm{CH}, J=1.2 \mathrm{~Hz})$, 7.45 (d, CHaromatic $J=1.8 \mathrm{~Hz}), 2.71-1.83\left(\mathrm{~m}, 8 \mathrm{H},-\mathrm{CH}_{2-}\right.$ cyclic); ${ }^{13} \mathrm{C} \mathrm{NMR}\left(\mathrm{CDCl}_{3}\right) \delta: 159.25,157.24,138.37,135.29$, 133.50, 132.96, 130.50, 129.23, 114.43, 107.46, 25.23, 24.24, 23.01, 21.94. EI-MS m/z (rel. int.\%): 302 (60) [M+1] $]^{+.}$; Anal. calcd. for $\mathrm{C}_{16} \mathrm{H}_{13} \mathrm{~N}_{2} \mathrm{SCl}$ : C, 63.89, H, 4.36, N, 9.31, Found: C, 63.85, H, 4.32, N, 9.28.

In vitro screening: Disc -diffusion and micro dilution assay: Antibacterial activity was done by the disk diffusion method with minor modifications. S. aureus, S. pyogenes, $S$. typhimurium and $E$. coli were sub-cultured in BHI medium and incubated for $18 \mathrm{~h}$ at $37^{\circ} \mathrm{C}$ and then the bacterial cells were suspended, according to the McFarland protocol in saline solution to produce a suspension of about $10^{-5} \mathrm{CFU} \mathrm{mL}^{-1}: 10$ $\mu \mathrm{L}$ of this suspension was mixed with $10 \mathrm{~mL}$ of sterile nutrient agar at $40{ }^{\circ} \mathrm{C}$ and poured onto an agar plate in a laminar flow cabinet. Five paper disks ( $6.0 \mathrm{~mm}$ diameter) were fixed onto nutrient agar plate. One mg of each test compound was dissolved in $100 \mu \mathrm{L}$ DMSO to prepare stock solution from stock solution different concentration $10,20,25,50$ and $100 \mu \mathrm{g} / \mu \mathrm{L}$ 


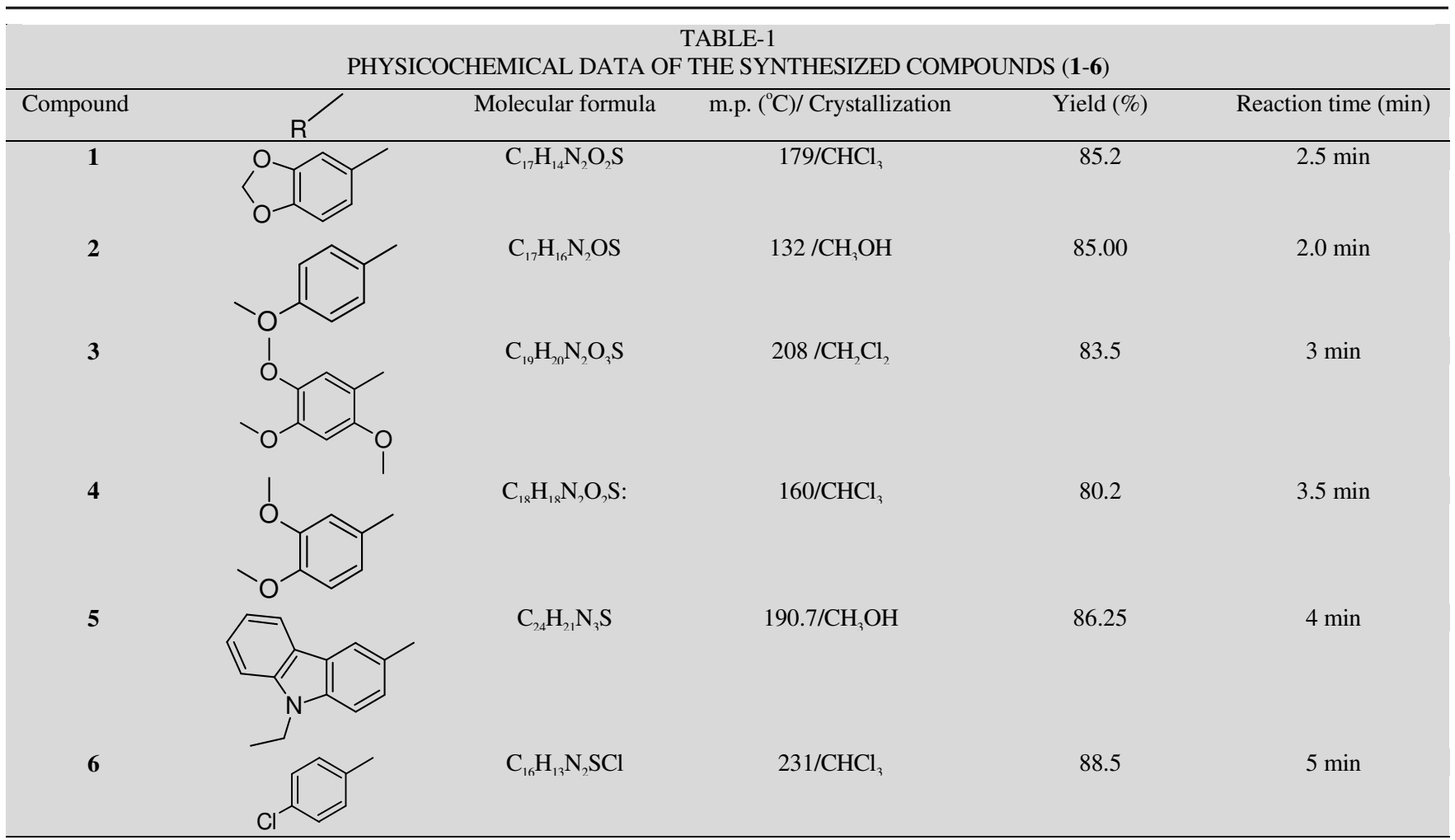

of each test compound were prepared. These compounds of different concentration were poured over disk plate on to it. Chloramphenicol (30 $\mu \mathrm{g} / \mathrm{disk})$ was used as standard drug (positive control). DMSO poured disk was used as negative control. The susceptibility of the bacteria to the test compounds was determined by the formation of an inhibitory zone after $18 \mathrm{~h}$ of incubation at $36^{\circ} \mathrm{C}$ (Table-2) reports the inhibition zones ( $\mathrm{mm}$ ) of each compound and the controls. The minimum inhibitory concentration (MIC) was evaluated by the macro dilution test using standard inoculums of $10^{-5} \mathrm{CFU} \mathrm{mL}^{-1}$. Serial dilutions of the test compounds, dissolved in dimethyl sulfoxide were prepared to final concentrations of 512, 256, $128,64,32,16,8,4,2$ and $1 \mu \mathrm{g} / \mathrm{mL}$ to each tube was added $100 \mu \mathrm{L}$ of a $24 \mathrm{~h}$ old inoculum. The MIC, defined as the lowest concentration of the test compound, which inhibits the visible growth after $18 \mathrm{~h}$, was determined visually after incubation for $18 \mathrm{~h}$, at $37^{\circ} \mathrm{C}$ and the results are presented in Table-3. Tests using DMSO and chloramphenicol as negative and positive controls.

\section{RESULTS AND DISCUSSION}

The synthesis of Schiff base derivatives is straight forward and the compounds were isolated in good yield. The derivatives were synthesized by using the literature procedure ${ }^{31}$. The obtained compounds are stable in the solid state as well as in the solution state. Physical data of the compounds (1-6) are given in Table-1. The analytical data of these compounds are in good agreement with their composition. The structure of all the compounds presented in experimental section was established by comparing spectral data (FT-IR, ${ }^{1} \mathrm{H}$ NMR, ${ }^{13} \mathrm{C}$ NMR, Mass) and elemental analyses. Assignments of selects characteristic IR band positions provide significant indication for the formation of the Schiff base derivative. The compounds showed intense bands at $1573-1558 \mathrm{~cm}^{-1}$ due to $\mathrm{v}(\mathrm{C}=\mathrm{N})$ stretch, which confirmed the formation of donor accepter dyes derivatives. Further evidence for the formation of Schiff base derivative was obtained from the ${ }^{1} \mathrm{H}$ NMR spectra, which provide diagnostic tools for the positional elucidation of the protons. Assignments of the signals are based on the chemical shifts and intensity patterns. The aromatic protons of Schiff base are shown as s,d and dd in the range (6.47-8.15) ppm for the compounds. A Singlet due to $1 \mathrm{H}$, CHolefinic, proton in the compounds was observed at (8.27-8.77) ppm respectively.

${ }^{13} \mathrm{C} \mathrm{NMR}\left(\mathrm{CDCl}_{3}\right)$ spectra of Schiff base derivatives were recorded in $\mathrm{CDCl}_{3}$ and spectral signals are in good agreement with the probable structures details of ${ }^{13} \mathrm{C}$ NMR spectra of all compounds are given in the experimental section. Finally characteristic peaks were observed in the mass spectra of Schiff base by the molecular ion peak. The mass spectrum of compound 2 shows a molecular ion peak $\left(\mathbf{M}^{+}\right) \mathrm{m} / z 298$.

Antimicrobial activity: Disc.-diffusion and micro dilution assay: The compounds (1-6) were tested for their antibacterial activities by disc-diffusion method using nutrient broth medium [contained (g/L): beef extract $3 \mathrm{~g}$; peptone $5 \mathrm{~g}$; $\mathrm{pH} 7.0]^{32}$. The Gram-positive bacteria and Gram-negative bacteria utilized in this study consisted of $S$. aureus, $S$. pyogenes, $S$. typhimurium and E. coli. In the disc-diffusion method, sterile paper discs $(0.5 \mathrm{~mm})$ impregnated with compound dissolved in dimethyl sulfoxide at concentration 100 $\mu \mathrm{g} / \mathrm{mL}$ were used. Then, the paper discs impregnated with the solution of the compound tested were placed on the surface of the media inoculated with the microorganism. The plates were incubated at $35^{\circ} \mathrm{C}$ for $24 \mathrm{~h}$. After incubation, the growth inhibition zones are shown in Table-2. The chalcone derivative was further checked by MIC method. The results are presented in Table-3. 
TABLE-2

ANTIBACTERIAL ACTIVITY OF SCHIFF BASE DERIVATIVE, POSITIVE CONTROL CHLORAMPHENICOL (CHLORA.) AND NEGATIVE CONTROL (DMSO) MEASURED BY THE HALO ZONE TEST (UNIT, mm)

\begin{tabular}{cccc}
\hline \multirow{2}{*}{ Compounds } & & \multicolumn{2}{c}{ Corresponding effect on microorganisms } \\
\cline { 2 - 4 } & S. aureus & S. Pyogenes & S. typhimurium \\
2 & $11.8 \pm 0.5$ & $11.2 \pm 0.4$ & $10.8 \pm 0.2$ \\
3 & $12.6 \pm 0.5$ & $11.6 \pm 0.4$ & $10.6 \pm 0.4$ \\
4 & $12.3 \pm 0.5$ & $12.8 \pm 0.5$ & $11.4 \pm 0.4$ \\
5 & $12.6 \pm 0.5$ & $13.2 \pm 0.5$ & $11.8 \pm 0.5$ \\
6 & $15.5 \pm 0.4$ & $15.6 \pm 0.5$ & $16.6 \pm 0.4$ \\
Chlora. & $17.4 \pm 0.4$ & $18.8 \pm 0.5$ & $18.6 \pm 0.4$ \\
DMSO & $17.0 \pm 0.5$ & $18.2 \pm 0.4$ & $17.5 \pm 0.5$ \\
\hline
\end{tabular}

TABLE-3

MINIMUM INHIBITION CONCENTRATION OF SCHIFF BASE DERIVATIVE (1-6) PRODUCTS, POSITIVE CONTROL: CHLORAMPHENICOL

\begin{tabular}{lccccccc}
\hline \multirow{2}{*}{ Bacterial strain } & \multicolumn{9}{c}{$\begin{array}{c}\text { Minimum inhibition concentration } \\
\left(\mu \mathrm{g} \mathrm{mL}^{-1}\right)\end{array}$} & compound & Positive \\
\cline { 2 - 8 } & 1 & 2 & 3 & 4 & 5 & 6 & Control \\
\hline S. aureus & 512 & 256 & 128 & 128 & 64 & 32 & 32 \\
S. pyogenes & 256 & 128 & 256 & 128 & 64 & 32 & 32 \\
S. typhimurium & 256 & 128 & 256 & 256 & 128 & 32 & 32 \\
E. coli & 512 & 256 & 128 & 512 & 32 & 32 & 32 \\
\hline
\end{tabular}

\section{Conclusion}

The novel Schiff bases thiophene containing nucleus were synthesized by the reaction of 2-amino-4,5,6,7-tetrahydrobenzo[b]thiophene-3-carbonitril and corresponding active aldehyde and were studied for their antimicrobial activity. The results of antibacterial screening reveal that among all the compounds screened, compound $\mathbf{5}$ showed moderate antibacterial activity while compound $\mathbf{6}$ displayed good antibacterial activity when compared with chloramphenicol used as standard. Particularly, compound $\mathbf{6}$ which is carrying chloro substituent appears to exhibit the highest antibacterial activity. Our experimental results were found in good corroboration with the theoretical results. Structure activity relationship studies revealed that chloro substituted derivatives play important role in antimicrobial activity. The present work suggests that there is need to develop nonantibiotic drugs, which may overcome antibiotic resistance. Such highly bioactive drugs preferably herbal preparations with least toxicity. A little structure variation can cause immense difference in the activity of the drug. This approach can open new vistas in the chemotherapy of the infective disease. The field is further open for pharmacokinetics and clinic studies to establish these molecules as drugs in the market.

\section{ACKNOWLEDGEMENTS}

This Project was funded by SABIC and Deanship of Scientific Research (DSR), King Abdulaziz University, Jeddah, under Grant No. 13/258/1432. The authors, therefore, acknowledge with thanks SABIC and DSR technical and financial support.

\section{REFERENCES}

1. F. Qadri, A.M. Svennerholm, A.S.G. Faruque and R.B. Sack, Clin. Microbiol. Rev., 18, 465 (2005).

2. W. Zhang, E.M. Berberoy, J. Freeling, D. He, R.A. Moxley and D.H. Francis, Infec. Immun., 74, 3107 (2006).

3. C.C. Butler, S. Hillier, Z. Roberts, F. Dunstan, A. Howard and S. Palmer, Br. J. Gen. Pract., 56, 686 (2006).
4. S.A. Puerto, G.J. Fernandez, L.J. Castillo, M. Jose, S. Pinoa and P.G. Anguloa, Diag. Microbiol. Infect. Dis., 42, 1513 (2006).

5. H. Schiff, Justus Liebigs Ann. Chem., 131, 118 (1864).

6. M.Y. Khuhawar, M.A. Mughal and A.H. Channar, Eur. Polym. J., 40, 805 (2004).

7. K. Nejati, Z. Rezvani and B. Massoumi, Dyes Pigments, 75, 653 (2007).

8. S. Alexander, V. Udayakumar and V. Gayathri, J. Mol. Catal. A., 314, 21 (2009).

9. R. Karvembu, S. Hemalatha, R. Prabhakaran and K. Natarajan, Inorg. Chem. Comm., 6, 486 (2003).

10. M.W. Sabaa, R.R. Mohamed and E.H. Oraby, Eur. Polym. J., 45, 3072 (2009).

11. Z.H. Chohan, S.H. Sumrra, M.H. Youssoufi and T.B. Hadda, Eur. J. Med., 45, 2739 (2010).

12. T. Rosu, E. Pahontu, C. Maxim, R. Georgescu, N. Stanica, G.L. Almajan and A. Gulea, Polyhedron, 29, 757 (2010).

13. N.B. Patel and J.C. Patel, Arabian J. Chem., 4, 403 (2011).

14. L. Cheng, J. Tang, H. Luo, X. Jin, F. Dai, J. Yang, Y. Qian, X. Li and B. Zhou, Bioorg. Med. Chem. Lett., 20, 2417 (2010).

15. A. Geronikaki, D. Hadjipavlou-Litina and M. Amourgianou, IL Farmaco, 58, 489 (2003).

16. M. Kritsanida, A. Mouroutsou, P. Marakos, N. Pouli, S. PapakonstantinouGaroufalias, C. Pannecouque, M. Witvrouw and E. De Clercq, IL Farmaco, 57, 253 (2002).

17. S.K.S. Hazari, J. Kopf, D. Palit, S. Rakshit and D. Rehder, Inorg. Chim. Acta, 362, 1343 (2009).

18. A. Karakas, H. Unver and A. Elmali, J. Mol. Struct., 712, 117 (2004).

19. L. Kong, Z. Li, T. Okamura, G. Ma, Q. Chu, H. Zhu, S. Tang, W. Sun and N. Ueyama, Chem. Phys. Lett., 416, 176 (2005).

20. I. Kaya, M. Yildirim and A. Avc, Synth. Metals, 160, 911 (2010).

21. N.A. Negm, Y.M. Elkholy, M.K. Zahran and S.M. Tawfik, Corr. Sci., 52, 3523 (2010).

22. J.G. Ghogare, S.V. Bhandari, K.G. Bothara, A.R. Madgulkar, G.A. Parashar, B.G. Sonawane and P.R. Inamdar, Eur. J. Med. Chem., 45, 857 (2010).

23. G. Zapata-Sudo, L.B. Pontes, D. Gabriel, T.C.F. Mendes, N.M. Ribeiro, A.C. Pinto, M.M. Trachez and R.T. Sudo, Pharmacol. Biochem. Behav., 86, 678 (2010).

24. S.V. Bhandari, K.G. Bothara, M.K. Raut, A.A. Patil, A.P. Sarkate and V.J. Mokale, Bioorg. Med. Chem., 16, 678 (2008).

25. Z. Li, Z. Gu, K. Yin, R. Zhang, Q. Deng and J. Xiang, Eur. J. Med. Chem., 44, 4716 (2009).

26. S.K. Bharti, G. Nath, R. Tilak and S.K. Singh, Eur. J. Med. Chem., 45, 651 (2010).

27. B.S. Creaven, B. Duff, D.A. Egan, K. Kavanagh, G. Rosair, V.R. Thangella and M. Walsh, Inorg. Chim. Acta, 363, 4048 (2010).

28. M.M. Aly, Y.A. Mohamed, K.A.M. El-Bayouki, W.M. Basyouni and S.Y. Abbas, Eur. J. Med. Chem., 45, 3365 (2010).

29. K.M. Amin, M.M. Kamel, M.M. Anwar, M. Khedr and Y.M. Syam, Eur. J. Med. Chem., 45, 2117 (2010).

30. M. Sonmez, M. Celebi, Y. Yardim and Z. Senturk, Eur. J. Med. Chem., 45, 4215 (2010).

31. H.M. Marwani, A.M. Asir and S.A. Khan, Russ. J. Bioorg. Chem., 38, 533 (2012).

32. A.M. Asiri and S.A. Khan, Molecules, 15, 4784 (2010). 